\title{
Business Strategy and Firm Reorganization under Changing Market Conditions
}

\author{
VIVEK GHOSAL
}

CESIFO WORKING PAPER NO. 2673

CATEGORY 11: INDUSTRIAL ORGANISATION

JUNE 2009

An electronic version of the paper may be downloaded
- from the SSRN website: $\quad$ www.SSRN.com
- from the RePEc website:
from the CESifo website: 


\title{
Business Strategy and Firm Reorganization under Changing Market Conditions
}

\begin{abstract}
This study is framed against the increasingly stringent environmental demands on the pulp and paper industry since the late-1980s to reduce water and air pollution, and the global economic slowdown of the early-1990s. The primary focus of this paper is an observationbased analysis conducted by visiting selected paper mills in Finland, the U.S., Germany and Sweden. I find interesting differences and similarities in the firms' strategies in terms of how they responded to these changes in market conditions. Some of the observed differences lie in their focus on achieving (incremental) cost-efficiency gains from better management of the production processes, inventories, supply-chain, product distribution, and timing of modernization investments, including ICT. The second part of the paper presents evidence on firms' productivity paths, and the heterogeneity in productivity among relatively similar firms. I also present selected evidence of these firms' investments in specific areas and how they affected their productivity. The observation of important intra-industry differences across relatively similar firms lends credence to the insights provided by Denrell, Fang and Winter (2003) and Zott (2003), among others. The findings have implications for the study of organizational behavior and business strategies employed by firms to improve their performance and productivity under changing market conditions. We end with some comments on how to assess innovative activity in traditional industries such as pulp and paper.
\end{abstract}

JEL Code: L00, L11, L20, L23, L25.

Keywords: incremental innovation, ICT investments, modernization investments, competitive advantage, production management, supply-chain management.

\author{
Vivek Ghosal \\ School of Economics \\ Georgia Institute of Technology \\ USA - Atlanta, GA 30332 \\ vivek.ghosal@econ.gatech.edu
}

June 2009

I gratefully acknowledge receiving funding for this project from the Center for Paper Business and Industry Studies (CPBIS, an Alfred P. Sloan Foundation Industry Research Center). For helpful comments on related versions of this paper, I thank participants at: CESifo workshop on Productivity and Growth (Munich, 2007); Strategic Management Society annual conference (Cologne, 2008); European School of Management and Technology (Berlin, 2008); workshop on "Organization and Performance: Understanding the Diversity of Firms" organized by Maison-Franco Japonaise (Tokyo, 2008); Jönköping International Business School (Jönköping, 2009); and the conference on "Advancing the Study of Innovation and Globalization in Organizations" organized by the German Institute for Employment Research and the European Cooperation in Science and Technology (Nürnberg, 2009). 


\section{Motivation}

Understanding how firms respond to changes in market conditions is a key area of research in strategic management. In markets in a state of flux, managers will quickly need to grasp the complexities of the changes, assess their resource-base, form expectations of their competitors' responses, evaluate the role of any rules and restrictions imposed by public policy, and act decisively to maintain or enhance their competitive advantage. In markets under flux, managerial cognition, ability to process and analyze new information, and the ability to act decisively may well be the difference between how the landscape looks once the dust has settled.

In a classic, Drucker (1995) examined a wide range of issues in this broad area and highlighted the role played by knowledge. Spender and Grant (1996) examined the role of knowledge in maintaining and gaining competitive advantage. While knowledge has many different facets and is relevant for myriad aspects of a firm's operations, in the context of this paper we focus on knowledge as pertaining to understanding the changes in the market conditions, knowledge of the firm's resource-base and operations, knowledge of various complementarities between different aspects of the firm's operations, knowledge of rules and regulations that might affect the firm's operations and how all this information can be processed to make optimal decisions.

The focus of this paper is to study the changes in the pulp and paper industry during the late1980s to late-1990s and examine how some of the firms in this industry responded to changes in market demand and supply conditions, and the environmental-regulatory changes. In the period under consideration, the pulp and paper industry is best treated as globally integrated in the sense that there were many large companies like International Paper, Stora-Enso, Weyerhauser, UPMKymmene, Georgia-Pacific, Norske Skog, Abitibi, Wausau Paper, Holmen, among others, which competed with each other in international markets. Each of these companies sold their paper and 
related products in several foreign destination markets. Each of these companies had complex inputsupply and product-distribution chains that threaded through different countries.

The early-1990s saw a worldwide economic slowdown; Table 1 presents data for the world real GDP growth as well as for North America and the broader EU-25. These data show a considerable slowdown in North American GDP growth during 1990-1992 and in the EU-25 between 1990-1994. Since the companies produce a range of paper, packaging and paperboard related products, their demand is quite cyclical. The economic slowdown in the two dominant economic markets (North America and EU) had a marked impact on the paper industry. This industry is also one of the most-capital intensive in manufacturing with a single-plant costing over \$2billion. The high fixed-costs imply significant economies-of-scale. Therefore, low demand and consequent market price drops can have a significantly adverse effect on profitability. From the late1980s and continuing through the mid-1990s, the industry saw sharp price reduction and falling profits.

The period starting in the early-to-mid 1980s also saw considerable changes in foreign competition (see Ghosal, 2002). Increase in containerization along with dramatic drops in shipping rates allowed firms to transport larger volumes to far away destination markets. The early-1990s global economic slowdown exacerbated these effects. As sales in existing markets dropped, producers of paper and related products scoured new markets to sell in as well as becoming more aggressive to increase sales in existing markets. European producers, for example, more aggressively sough to increase their presence in the U.S. markets and vice versa.

The industry is also subject to significant environmental regulations. As noted in Li, McCarthy and Urmanbetova (2004), the U.S. environmental regulations - the Clean Air and Clean Water Acts in the late-1960s and early-1970s - required pulp and paper companies to limit the 
amounts of pollutants discharged into the air and water and invest in new pollution-control technologies. Some of the processes that were affected by the Federal Water Pollution Control Act Amendments of 1972 included mechanical pulp, non-wood chemical, secondary fiber deink, fine and lightweight papers from purchased pulp, and the categories of tissue, filter, nonwoven, and paperboard from purchased pulp. The Solid Waste Disposal Act of 1980 had a marked effect on the industry as dioxin, chlorine and chlorine derivatives were considered hazardous waste substances and these wastes had to be disposed according to the federal requirements. Starting in 1995, under the Great Lakes Initiative, pulp and paper companies located in the eight states bordering the shores of the Great Lakes had to control the release of bio-accumulative industrial chemicals, pesticides, and metals that posed a broad range of health risks. Compliance with this initiative was expected to cost the companies over \$1billion in new investments. Finally, the Cluster Rule started in 1993 was designed to integrate the Water and Air regulations into a consistent and non-exclusionary body of rules. The production facilities were expected to install the maximum achievable control technology. The estimated cost to the industry would be in the $\$ 2-2.5$ billion. In Europe, particularly Northern Europe and Scandinavia, the environmental standards were being raised even further. One important difference between the U.S. and, for example, Scandinavia, was that while both had the introduction of significant environmental regulations, the "enforcement" standards were somewhat different across these jurisdictions. While the U.S has fluctuated between periods of relatively stricter versus lax enforcement under different political administrations, the Scandinavian countries have had relatively more consistent and stricter enforcement. This, as we discuss below, has implications for the business strategies pursued by the U.S. firms versus their European counterparts.

The primary focus of this paper is to examine how some of the firms responded to this new market reality. Section 2 briefly describes the key characteristics of the paper industry. Section 3 
briefly comments on some data issues. In Section 4 I present the qualitative information and inferences from my visits to selected paper mills. Given the firms' focus on cost-efficiency and productivity, in section 5 I briefly discuss linkages to some theoretical models. Section 6 examines data on productivity for selected multinational firms in this industry and presents cross-firm labor productivity regression results. In section 7 I discuss insights from the strategic management literature regarding differences across firms and some of the underlying explanations. Section 8 discusses some insights for managers, and concluding remarks on measuring innovation in traditional industries appears in section 9.

\section{Industry Characteristics}

Before we delve into issues that are at the heart of firms' strategy, we describe the nature of the products and technology for the firms in the pulp and paper industry. Firms in this industry typically produce differentiated and diversified products: (1) various types of paper such as standard writing paper, glossy paper, high-speed copier and printer paper, newsprint, envelopes, and other specialty papers; (2) pulp; (3) various types of packaging paper and materials; (4) paperboard; (5) tissues; and (6) wood products such as flooring and shelving materials. The process of making paper has not fundamentally changed in a long time. The important steps in the production process are: (1) debarking the timber logs, chipping and/or recycling, (2) pulp preparation, (3) paper formation, and (4) paper finishing. The underlying technology and the processes are reasonably standardized and well known. Modern papermaking, however, has evolved into a complex industry. The integrated papermaking machine is very costly and, at current prices, can cost between $\$ 600$ million to $\$ 1$ billion. Papermaking machines are long-lived and can last for many decades. However, with newer and faster machines, along with improvements in waste (liquids and solids) management, the 
meaningful life of the machine - in the sense of what it would take to stay highly competitive and meet the changing environmental standards - is likely to be shorter. Given the high fixed-cost, firms have to make careful long-run projections about the market conditions and their business strategies before embarking on new investments. The pulp and paper companies - like International Paper, Stora Enso, Weyerhaueser, Georgia Pacific, UPM-Kymmene, among others - are producers of various types of paper as noted above. They buy the papermaking machines from a range of international suppliers (e.g., Valmet, Voith, Andritz-Ahlstrom, Beloit, Groupe Laperrière \& Verreault, among many others). In this sense, the core technologies for production of paper are provided by external manufacturers and are accessible to all. The technologies are developed by the suppliers independently as well as with considerable feedback from the paper companies (i.e., codeveloped). The paper companies, however, have some opportunity to tweak various aspects of the production processes, make modernization investments and engage in learning-by-doing, with the objective of increasing the cost-efficiency of production and gaining some productivity advantage over their rivals. Later, in section 5, I briefly discuss some theoretical models that provide insights into firms' productivity-enhancing activities.

There are two noteworthy aspects of the supply-chain and its management. First, in the initial stages, it relates to forestry. That is, how the contracts for timber logs are structured and transportation of the logs to the mills. In a country like Finland, over $75 \%$ of the forests are privately owned and an important fraction is owned by individuals. As noted by Barsky (1999), "about one in five families in Finland owns a portion of the nation's forests, a unique situation which has given the forest a special place in the lives of Finns - and the people a special interest in their conservation." These individuals consider their trees to be their short-and-long run income. Given the relatively long growth-cycle of the trees, this, for example, implies that they will typically not allow the paper 
companies to clear cut as it will affect their income in the ensuing years. Similarly in Sweden, private companies own close to $25 \%$ of the forests and individuals about $50 \%$. In most other countries, the percentage of private, especially individual, ownerships of forests is lower. This has important implications for the supply-chain management by the pulp and paper companies in the Scandinavian versus many other countries. Second, in the final stage, it relates to contracts for transporting the finished paper products via truck, train and ship to destination markets. If markets become more volatile compared to historical standards, presence of longer-term contracts with transportation companies can become rather costly and burdensome. Paper mill managers will have to rethink all of their transportation contracts to make it more conducive to current market conditions.

Other important aspects of this industry include:

(1) Relative lack of ability to differentiate products within a "given category" such as printer paper, magazine paper, among others. This is due to existing knowledge of processes and the rivals' ability to relatively easily reverse-engineer the products; and

(2) Lack of pricing power by individual firms. Given the nature of the production technology, market structure and market conditions, the best way to model competition in the pulp and paper industry is to assume Cournot quantity competition (see, for example, Pesendorfer, 2003).

This implies that if a firm has to gain any advantage over its rivals within a given product category, it will have to come from the cost side. These include efficiencies that can be generated from changes in the firm's organizational structure or generating production cost-efficiencies from making adjustments to the production processes. 


\section{Data and Information}

The standard data that are available for the firms in this industry - e.g., from Compustat, Amadeus, Thompson's Financials, and several sources specific to the paper industry - are rather aggregated (to the firm level) and appear to be inadequate to understand the complex set of issues and changes. For example, whether a firm reorganized its internal organizational structure, input supply-chain, or product distribution chain in response to changing market conditions, how it did it or what specific aspects of it were changed would not be discernable from these standard data sources. Given this, the primary focus of this paper is to provide detailed descriptions of changes and firms' strategies from my visits to paper mills, and complement these with a limited amount of standard quantitative data.

My primary interest was to examine the micro-level decision- making to gain insights into the business strategies pursued by firms in the pulp and paper industry under the changing market conditions. Given this, the primary mode of analysis and information gathering was observationbased - i.e., visiting paper mills. I visited selected paper mills in Finland, Germany, the U.S. and Sweden, toured their production facilities, and interviewed their production, environmental and other managers in order to gain insights into how they viewed the challenges and the changes they made. In addition, I conducted brief interviews of selected industry specialists to verify some of the information and gain additional insights. After having gone through this process, it seems that the standard data that are available for analysis are rather inadequate to address the complexity of the issues under consideration. Section 4 presents our inferences from the visits to paper mills.

The second part of the paper presents a limited amount of evidence from data and information that were compiled from standard sources as well as collected from industry-specific 
sources. The data include the standard data from Compustat on the firms' sales revenues, labor input, gross investments, capital stock, R\&D expenditures, among others. The data also include firm-specific data that were collected from various issues of the industry publication Pulp and Paper on specific areas of investments such as ICT, digital monitoring devices, mechanicals, among others; these data are fully described in Ghosal and Nair-Reichert (2009). Using these data, section 6 provides selected evidence on firms' productivity paths.

\section{Visits to Paper Mills and Learning about Business Strategies}

In this section I summarize the observations and inferences from my pulp and paper mill trips and draw some inferences on the firms' responses to the changes in the economic environment. While I have visited pulp and paper mills in Finland, the U.S., Germany and Sweden, below I summarize my inferences and observations from the first two visits which are sufficient to highlight some of the key issues confronting the firms in these markets.

\subsection{Visit to a Paper Mill in Finland}

The mill in Finland ${ }^{1}$ was an integrated ${ }^{2}$ pulp and paper mill that used state-of-the-art production processes and their primary focus was on printing and copying papers, uncoated fine papers, and specialty papers such as digital papers and high quality labels. Of their total production of printing papers, about $50 \%$ is accounted for by magazine papers and the rest by newsprint and fine papers. The total production capacity of the mill was close to 1 million tons of paper per year. I met with their production manager, environmental manager, R\&D executives, labor relations

\footnotetext{
${ }^{1}$ As was agreed to before the mill visits, I do not disclose the location of the mills or the parent companies.
} 
personnel and asked them questions regarding their operations, technologies and the changes they have made since the economic slowdown of the late-1980s and early-90s period. Below is a rendition of what I learnt.

They indicated that following the economic downturn of late-1980s early-1990s, they had instituted several major changes in how they do business. During the 1990-91 downturn, they had significant problems with excess production and pileup of wood inventory. During that period, they were forced to sell even when the market was down and prices were low. All of this was the result of their relatively inflexible input-procurement and transportation contracts, ${ }^{3}$ and production. Postrecession, they embarked on an efficiency drive; sort of, a cleansing effect of the recession. ${ }^{4} \mathrm{An}$ important future objective was to reduce production and sales when prices were low. Below I present some of the details.

They restructured their timber procurement contracts to make it more flexible so that they could hold less inventory of timber logs and chipped wood at the mill. Their contracts with the farmers (who along with the government own approx $90 \%$ percent of the forests) for timber logs were made a bit more flexible, allowing them to increase or decrease the supply of logs (within prespecified limits) reasonably quickly. Earlier, under the more inflexible and longer-term timber contracts, they were holding stocks of logs and chips worth about 2-3 months of input usage, and the timber would keep flowing in even when demand was low. According to the mill managers, this typically meant that even when the market was down and the selling prices were low, they were forced to use up the timber, produce and sell. In the 1990s, they gradually reduced the inventory to

\footnotetext{
${ }^{2}$ A non-integrated mill, for example, could only produce only paper or produce (market) pulp.

${ }^{3}$ Inflexible in the sense that their timber input contracts were relatively longer term. This afforded them little opportunity to cut costs and scale down production quickly during downturns.

${ }^{4}$ Ince (1999) points to some of these issues as problems for the U.S. industry.
} 
about 10 days supply of chips and 4 days of logs for a total of 14 days worth of input. This was a sharp reduction of inventory holdings of the critical input of timber logs and chips. These changes in the input-procurement contracts implied that they could ramp production up or down by a significant percentage in a short time frame. With these changes, they mentioned that they could increase or decrease production by $10 \%-15 \%$ within a few days, allowing them to better tailor production to the market demand conditions.

Holding smaller inventory of timber logs and wood chips had dramatic effects on the production process. Only 14 days of inventory meant that the wood was relatively fresh and the fibers had not degraded. First, if the wood chips are fresh, the pulp fibers need less chemicals, treatment and processing (less brittle and longer fibres produce higher quality paper and require less chemical processing). Higher quality paper could be produced at lower cost. If the chips are older (sitting out in the yard, rain or shine, for months), the fibers degrade and need more chemical processing which raises the cost and reduces quality. To increase quality of the finished product, they would have to undertake more chemical processing and apply additional coating(s). Second, since less chemicals and processing were required with fresher wood chips, the amount of pollution generated at the back-end was lower. This reduces the cost of cleanup. Overall, fresher wood chips resulted in lower unit cost (of production and cleanup) and higher quality. In combination, these set of changes had an appreciable effect on the paper mill's cost-efficiency (which includes both production costs as well as environmental cleanup costs).

At the other end of the supply-chain, they restructured their transportation contracts for shipping out the finished product. Earlier, they had relatively inflexible longer-term contracts. They changed these to make them more flexible. The mill uses both rail and truck transport; rail tends to be more inflexible. Under the new structure, they had a smaller core of longer-term contracts and the 
remainder they use whatever flexibility is available in (mainly) truck and (some) rail.

Overall, there were dramatic changes in the entire supply-chain. Their mantra: greater flexibility, lower costs, and higher quality. Because of this flexibility in input procurements and transportation of the final product, they could now reduce production when the markets were down and prices low. Accordingly to the mill managers, the changes they instituted had significant impact on efficiency.

Next we turn to the production process itself. The mill managers indicated that the papermaking machines were available to all who could buy them, and the basic production processes used by various competitors were relatively common knowledge. In this sense, it was unlikely that, on average, the machines were a major source of advantage across producers in the key countries; if producers in Sweden, Germany or Finland had access to certain machines/technology, producers in the US, Canada and other countries would have access to it as well. There are, of course, differences based on vintage of machinery as well as some differences in the chemicals and processes used in pulping, among others. Given this, one would typically not look at differences in core technologies and production processes themselves to identify differences in efficiency levels and comparative advantage across firms in this industry, keeping in mind the capital-vintage caveat.

The mill managers greatly emphasized, what they termed, "de-bottlenecking" and incremental efficiency gains: the right amount, at the right time. De-bottlenecking refers to carefully examining each component of the large and complex production process and evaluating if there were any bottlenecks within a given unit (such as pulping or bleaching) or whether there were any general problems that affected the entire production process (for example, excess of chemicals or inappropriate chemical mix in one stage could affect the quality of the final product as well as increase environmental clean-up costs). They noted that by meticulously de-bottlenecking on a 
consistent basis, they were effectively increasing production capacity by about $1.5-2 \%$ per year without any new capital investments. In effect, successful de-bottlenecking amounted to incremental innovation with resulting lowering of the firm's cost function and generating higher output in equilibrium. The mill managers indicated that the incremental efficiency enhancements saved them between $5 \%-10 \%$ per year in terms of operating costs. They viewed this as vital to the firm's survival and competitive edge in the longer-run. The cost efficiency gains, which arose from chemicals, mixing and process improvements, were viewed as critical since new capital investments were typically very expensive.

In the area of information and communication technology (ICT), there was dramatic evidence. Side-by-side, in one building they had an older pulp and paper mill that produced uncoated, relatively basic, paper. In the adjoining building, they had their newest machine which produced their flagship products which included high-speed printing and specialty papers. Around the older machine, there was much greater labor activity - people trying to monitor and fix things and less computerization. For the newer machine, almost everything - entry of wood chips into the system, pulping, mixing of chemicals, etc - was controlled via centralized computer terminals networked with digital cameras and digital monitoring and recording devices. Each stage of the production process could be monitored closely via these terminals. Workers in charge of monitoring and adjusting the systems, had a lot of discretionary power to "fix" problems, which included significantly changing the machine speeds and even shutting it down if needed. The production managers mentioned that such decentralization in decision-making was necessary in order to avoid production slowdowns and stoppages. To make this operational, they had to train specific workers to operate and manage this integrated ICT system. They incurred significant training costs and timeover a year of training for each of the individuals who would operate the integrated system. Their 
mill managers boasted that "... we may have the most trained and skilled labor force in the whole industry." Incorporating ICT into the production process also meant that problems in the production line could be spotted faster, a better diagnosis made faster, and the decision to slow down the process was made faster. Faster identification and fix for the problem meant that there was less degraded (due to glitches in the production process) paper coming out at the end. Overall, computerization and technical change was obvious, the human-capital embodied in their workforce seemed high and the efficiency gains were palpable.

To make the induction of ICT and other changes work better, they instituted an incentive program for labor. Workers are encouraged to report their ideas about improving productivity and lowering costs to management. They had a carefully-crafted mechanism for determining the merit of these suggestions and appropriately rewarding the workers, if the suggestions were accepted and incorporated. These were designed to keep them a step-ahead of their competition and improve worker productivity and morale.

In terms of complimentary resources, they placed much greater emphasis on in-house energy generation. It is useful to keep in mind that pulp and paper production is highly energy-intensive. They argued that this would produce significant cost-saving in the longer-run. The payback period for going in-house on energy was about 4-5 years and, therefore, having in-house energy generation was a bargain in the longer-run.

Finally, there were significant changes in management-labor relationships. After the 1990-91 downturn, it became clear they had to reorganize. Labor unions in Finland are very strong and initially resisted the management's approach to reduce labor, increase capital-intensity, incorporate more ICT and modernize. However, after a prolonged period of negotiations (between 4-5 years) and impressing on the unions that modernization was vital to the firm's survival, they succeeded in 
making the changes. There were minimal layoffs, and the future growth of the firm would come from growth of capital and technology and not additional labor. They achieved their optimal targets for labor by attrition - not replacing many of those who retired. At the time of my visit, the mill managers said that they had bottomed out on the labor-saving aspect; i.e., in the near term, no further gains are possible in this dimension. To put it differently, capital-and-technological intensity appeared to be at their peaks.

\section{A key theme from my mill visit in Finland}

The mill executives in Finland noted that producers in the industry typically have little pricing power. Further, gaining pricing power through product differentiation was difficult as imitating a competitor's new paper products was generally not difficult. All of this implied that, to be profitable, one had to be efficient and reduce costs.

The mill managers had a single-minded focus on incremental innovations and efficiency enhancements: the right amount at the right time! They were not searching for the big-bang technological improvements that would put them ahead of their competitors. But a lot of attention was paid to making the existing machinery and processes work better. They thought through the various complementarities in the production processes and supply-chain on a regular basis and were determined to tweak even small amounts of extra output from the existing machines. The mill managers commented that their US counterparts typically did not focus as much on incremental cost efficiency enhancements during the 1990s. They said the US manufacturers were starting to do this now, but they felt that the US efforts to catch up on efficiency may be a too little too late. ${ }^{5}$

\footnotetext{
${ }^{5}$ In a related context, some of the issues highlighted in section are noted in McNutt (2002, p.13) as challenges for the U.S. producers in an increasingly global marketplace for the pulp and paper industry. See, for example, the discussion related to employee training and development, workplace transformation, capital
} 
Finally, the big beast: environmental regulation. Finland has tough environmental standards. And these high hurdles were getting even higher. In part, the mill managers saw some of the changes described above, like using fresher wood chips and less chemicals, as contributing to significant improvements in their environmental efficiency. Rather than fight the regulators and the system, they decided to go to the other extreme and modernized their plants, restructured the supply chain and exceed the environmental standards. The mill managers noted that this has paid significant dividends in their production efficiency, relationship with local communities, and federal and local environmental regulators. Portraying the right "environmental image" to the public and regulators was a very important part of their business strategy. In trying to attain or exceed the environmental standards in Finland, they succeeded in making significant gains in production efficiency, giving them a leg-up on some of their rivals. In part, this looks like a story of how regulation may help improve firms' competitive advantage.

\subsection{Visit to a Paper Mill in the U.S.}

The integrated pulp and paper mill I visited in the U.S. produced a range of fine white paper including copier paper, business forms, envelopes and writing materials. The mill had two papermaking machines that made medium and light weight paper. One started early-1980s. The second in early-1990s. The total investment cost was close to $\$ 1.5$ billion. (To be clear, this investment is for one mill.)

At the planning stage, it was recognized that future environmental standards would become more stringent. This consideration was built in during the construction phase and cost approximately $5 \%-6 \%$ of the total investment. The mill incorporated advanced water treatment and waste disposal

spending efficiencies, global supply chains, among others. 
facilities. The mill also had co-generation of electricity with over $70 \%$ of its energy requirements being generated in-house. The mill manager noted that if they did not build in these superior environmental control processes at the time of construction, but had to modify the mills later, the costs would be substantially more: roughly three-four times higher. They indicated that modifying older mills to meet new environmental standards is very costly.

With regard to transportation of the final product: about $20 \%$ rail; $75 \%$ truck; $5 \%$ smaller vehicles (this was expected to increase to about $10 \%$ to increase flexibility to serve local and regional customers). They indicated that rail is very inefficient. Truck and other smaller vehicles can deliver on-time at short notice. The mill manager noted that this was important for establishing good buyer-seller relationships.

The economic downturn late-1980s to early-1990s resulted in significant excess supply of paper in the market, resulting in lower prices and profits. All companies were hurting. The mill manager described it as the "big squeeze." This resulted in suppliers looking for newer markets to sell and opened up global markets. The mill manager noted two issues that producers needed to focus on: (a) look for buyers outside their traditional markets; and (b) be aware of foreign producers attempting to enter local markets. To protect their local and traditional markets, the mill paid greater emphasis on buyer-seller relationships, price competition and quality control (high quality as well as consistency of quality across different orders). Since the mid-1990s, there was need for greater awareness of foreign suppliers who may enter the producer's market.

The mill manager noted that for his mill, the traditional focus was on inventory management. Under the changing market conditions, the focus on inventory management was reduced, and much greater emphasis was put on process and supply management. In a nutshell, the whole focus shifted to short-term demand-supply matching. 
Since the late-to-mid-1990s, the mill placed greater emphasis on incremental innovation and de-bottlenecking to stay competitive and reduce costs. Given the relatively long-lasting and expensive nature of capital (paper mills), the mill manager noted that improvements in costefficiency would have to come in the form of incremental improvements.

In terms of R\&D expenditures as traditionally defined, there is very little. Instead, a lot of it involves tweaking existing processes to extract greater output and increase efficiency. The mill managers indicated that close to one-thirds of their technical staff devote significant amounts of time on such incremental process innovations. The mill manager offered two quantitative measures: (a) he indicated that $1-2 \%$ of revenues go towards activities in the area of cost efficiency enhancements; and (b) in terms of gains in output of paper, these efficiency enhancements had resulted in approximately $1.25 \%-2 \%$ per year growth in production. This may not seem overwhelming in any given year, but the compounded effect on cost efficiency and production gains can be significant in the longer run.

Their typical inventory holding of timber logs and wood chips was about 3 weeks; down from 2 months or more some years back. Timber was mainly trucked in using independent contractors. They indicated some inflexibility due to the work-schedules of these contractors (who worked 4 days/week). The mill manager noted that they could store timber logs and wood chips in moist climate-controlled conditions to minimize the effects of aging of the wood chips and fibers.

Due to increased computerization, worker training and human-capital has increased. Cameras and other electronic devices monitor production processes which the workers can keep track from computer terminals. Workers have leeway in addressing problems as they occur.

The particular US mill I visited was non-unionized. The mill manager noted that this was a big advantage for his mill compared to many other mills which were unionized. The company 
provides worker incentives. The focus is more on teamwork rather than individuals. If worker-teams suggest cost-saving innovations which are eventually adopted, workers receive some financial rewards.

\subsection{Comparing the Mill Visits}

I present a comparison from the mills I visited in Finland and the U.S. ${ }^{6}$ The important similarities and differences were:

(1) Managers at both mills emphasized that following the economic downturn of the 1990s, restructuring of the supply-chain and better process-management were essential to stay competitive. These included changes in the inventory holdings of logs and wood chips, emphasis on debottlenecking of the production process, offering workers incentives to be more productive, incorporating modernization via information technology investments for better process and overall business management, training their workers to ensure they could fully reap the benefits of the newer technologies including ICT, and restructuring transportation contracts.

(2) An important difference was that the mill in Finland did not have climate controlled storage for wood chips. The US mill had fairly advanced climate-controlled storage. The Finnish mill relied on timely delivery of logs to minimize decay of wood fibers. The end result appeared to be similar, but with very different mechanisms of getting to it.

(3) Both mills had relatively newer machines that were efficient at high production volume and met or exceeded environmental standards. The mills were clean, appeared to be efficiently managed, had a high level of ICT investments, and had made a number of organizational changes to meet changing

\footnotetext{
${ }^{6}$ The mill I visited in Germany was rather different and was undergoing significant changes to increase productivity, replace outdated machinery and implement changes in the organizational structure. The mills I visited in the U.S. and Finland were the high-efficiency models the German mill was trying to
} 
market conditions.

(4) While both appeared to emphasize de-bottlenecking and incremental cost-efficiency gains as key to survival, the production and mill managers in Finland emphasized this as their mantra. At every step of the way during my visit, they kept emphasizing how this "incremental attitude" had been ingrained into their management teams and workers. The US mill manager seemed somewhat less focused on this. He commented that “... we are getting around to doing this in a more effective manner...”

(5) Both said that gains in output due to cost-efficiency enhancements appear to be in the $1.25 \%-2 \%$ per year range. This was somewhat surprising given that it was coming from mills that were geographically so far apart and that there were several important differences in the nature of the changes the mills had made.

(6) The US mill manager was very focused on buyer-seller relationships. He noted that from his vantage point, price was not often the primary determinant in making a sale. Right quality, consistency of quality, on-time delivery, and attending to the "businesses idiosyncratic needs" were very important. In my discussions, the mill managers Finland did not bring up this issue at all. Their main, and consistent, comments were that they had little pricing power and had to rely on quality and cost-efficiency to stay competitive.

(7) The mill in Finland was unionized. The US mill was not. The former laid enormous emphasis on union-management relationships and how negotiating the introduction of new technologies and reducing employment via retirements was critical to their change in fortunes in the 1990s.

(8) The mill in Finland restructured their timber procurement contracts to make input supplies more flexible. One of the important points was to put in fresher wood chips into the production process.

follow. 
The US mill manager did not talk much about timber procurement contracts. Instead, he talked about climate controlled storage for timber logs and wood chips. End result: fresher wood chips into the production process. It is not clear to me how these differential strategies affect their costs. My gut sense was the US mill had to incur higher costs of climate controlled inventory.

(9) There appears to be some differences in the tax codes between US and Finland which allows the latter to make costly modernization investments - in particular greener technologies - on a more consistent basis. If so, this would be important in maintaining and enhancing efficiency. This came up only briefly during my conversations and I could not get a proper sense of the differences in the tax codes.

(10) The US mill complained about being constrained by "Wall Street considerations" when making large investments of the sort required to upgrade to newer mills or make costly modernization investments. The managers of the mill in Finland did not consider this to be a problem; they said that European stock markets are more forgiving of such investments. If so, this could potentially affect the long-run competitiveness, productivity and profitability of the industry. Super fast machine speed and width are the hallmark of the modern generation of papermaking machines. The US mill manager lamented: “ ... at one time the Americans had all the biggest and fastest machines. Now others increasingly have them ..."

\section{Linkages to Some Theoretical Models}

One of the themes that emerged from my visits to the paper mills was the firms' focus on implementing a range of solutions (described in section 4) that would provide gains in costefficiency and increase productivity. Aside from my own inferences from the mill trips, evidence indicates that there have been relatively little "major" technological change in the industry over the 
last couple of decades. Whatever changes have occurred have been primarily driven by environmental regulation. In the context of bleaching technologies, see Norberg-Bohm and Rossi (1998) for a discussion of how the industry has responded to this challenge. They note (p.237-38) that, due to the nature of EPA's balancing of costs and benefits in regulatory decision making and other factors, most of the technological advances have been "relatively incremental and radical transformation is rare." The paper and pulp industry employs myriad technologies ranging from those embedded in physical plant and equipment to those in different pulping processes. The technical life of paper machines, for example, appears to be in the 20-30 year range and investment costs are extremely high making it somewhat difficult to rapidly induct new technologies. In view of this, it may be particularly important to evaluate the role of incremental innovations which lead to gains in cost-efficiency and profitability. For the first half of the 1990s, Bjorkman, Paun and Jacobs Young (1997, p.80) note that most investments by U.S. and Canadian firms were typically not for new production capacity, but on incremental increases in production efficiency.

In this section I briefly discuss two classes of theoretical models that help focus our understanding of the firms' cost-efficiency and productivity-enhancing activities.

The first model described is a standard model of quantity competition. From my observation from the mill visits and review of the paper markets, two important features emerged. One, the products within each category - e.g., plain paper, different types of glossy paper, newsprint, etc, are best treated as relatively homogenous. While there are some differences, these differences are not likely to persist over time: the characteristics of a particular type of paper can be reverseengineered relatively easily and imitated by at least all the major players in the market. Therefore differences in attribute or quality across the firms are likely to evaporate relatively quickly. ${ }^{7}$

\footnotetext{
${ }^{7}$ Note that smaller firms can exist in these markets (for example, Sweden's Munksjö AB) that either serve
} 
Pesendorfer (2003), for example, strongly argues in favor of product homogeneity within a category. Two, based on my interviews with several managers, there did not appear to be a case where the firms in this industry were engaging in price-setting behavior. Several of the industry studies have mentioned how the firms had little/no pricing power and, in the 1980s and 1990s, were embarking on a path of increased M\&As to try and reduce capacity via plant closures post-merger. As has been discussed in the industry literature, this strategy too failed in part due to the overcapacity being too large to begin with, along with new entry of Australian, South American and Asian firms.

Given this, it seems best to characterize this industry as one with quantity competition with relatively homogenous products (within a category, as noted above), and an N-firm Cournot-Nash equilibrium. Pesendorfer (2003) who examines M\&As in this industry, models competition in capacities as one-shot Cournot. Given a production function (a la Dixit, 1980), we can think of a proportionality between a firm's capacity, $\mathrm{k}_{\mathrm{i}}$, and output, $\mathrm{q}_{\mathrm{i}}$. To illustrate the issues, consider a static Cournot setting with three firms. Let the $\mathrm{i}^{\text {th }}$ firm face a constant marginal cost $\mathrm{c}_{\mathrm{i}}$ and market demand is given by $P=a-b Q$, where total market output $Q=\left(q_{1}+q_{2}+q_{3}\right)$. Solving for the Cournot-Nash equilibrium, we get the equilibrium output for firm 1: $q_{1}^{*}=\frac{\left(a-3 c_{1}+c_{2}+c_{3}\right)}{4 b}$, where ' $\mathrm{a}$ ' is the demand function intercept, and $c_{1}, c_{2}$ and $c_{3}$ are the three firm's marginal costs, respectively. Firm 1's profits are given by: $\pi_{1}^{*}=\frac{\left(a-3 c_{1}+c_{2}+c_{3}\right)^{2}}{16 b}$. In this model with homogenous products, a firm's output, market share and profits depends on how cost-efficient it is compared to its rivals. Suppose we start with identical marginal costs for all firms: that is, $c_{i}=c \forall i$. Here, in equilibrium, each firm's output will be: $q_{i}^{*}=\frac{(a-c)}{4 b}$, and the three firms will have equal market share of $1 / 3$. Now let firm 1 be successful niche segments or relatively local markets. The focus of my study is on the larger players in the global markets. 
in achieving some gains in production efficiency due to learning-by-doing or reconfiguring it supply-chain or making critical modernization investments at the right time to upgrade its production process. Note that in the general expression for $q_{1}^{*}$ and $\pi_{1}^{*}$, the partial derivatives are $\partial q_{1}^{*} / \partial c_{1}<0$ and $\partial \pi_{1}^{*} / \partial c_{1}<0$. This implies that if firm 1's marginal cost $\mathrm{c}_{1}$ decreases, its equilibrium output and profits increase relative to its rivals. The intuition is that the best-quantity-response-function of the firm that achieved a cost-efficiency gain shifts to the right, giving it, in the new equilibrium, greater output sold, higher market share and profits compared to its rivals.

In this quantity-setting game, even small gains in cost-efficiency will translate into potential gains in output, market share and profitability. If these efficiency gains can be sustained and not mimicked by rivals - as could be the case for idiosyncratic firm-specific learning-by-doing, reorganization of supply-chain and production processes - they could form the basis of at least some persistence in efficiency and performance differences across firms in the short-to-medium run. To illustrate this point, it is useful to think about the marginal costs for each firm being given by: $c_{i, t}=c_{0} \theta^{-\left(1+g_{i}\right)^{t}}$, where ' $\mathrm{i}$ ' indexes the firm and ' $\mathrm{t}$ ' indexes time $(\mathrm{t}=0,1,2,3 \ldots)$ and $\mathrm{c}_{\mathrm{i}, \mathrm{t}}$ is the marginal cost for firm $i$ at time $t$. On the right hand side, $\mathrm{c}_{0}$ is a constant and $\theta$ is a parameter that indexes technological change - as indicated by increases in cost efficiency - with $\theta \geq 1$. In the exponent of $\theta$, $\mathrm{g}_{\mathrm{i}}$ represents a fraction $\left(g_{i} \geq 0\right)$ indicating the gains in cost-efficiency. As we move forward in time, the MC curve for a firm, $\mathrm{c}_{\mathrm{i}, \mathrm{t}}$, will drift down due to potential learning-by-doing effects, adoption of new processes, and making new investments in modernization, among other factors, which improves cost-efficiency and productivity. Since $\mathrm{g}_{\mathrm{i}}$ is firm-specific, firms can achieve differential rates of costefficiency gains; the higher is $g_{i}$ the faster will that firm's MC drift down. In the Cournot model, a positive $g_{i}$ implies that the firm's quantity best-response-function will move further rightward over 
time compared to its rivals and, ceteris paribus, will see increase in market share. This result corresponds to our analysis for differential cost-efficiencies across firms and the market outcomes related to quantities, profits and market shares.

The second class of models relate to those that highlight incremental innovation and cost efficiency gains. The literature on innovation has extensively analyzed the role of major and incremental innovations. Major innovations play a role in birth of products and dramatic changes in the competitive landscape. Such changes are, however, infrequent. Incremental innovations, which can arise from learning-by-doing, are more frequent and can play a significant role in firms' year-toyear strategic decisions. As is standard in this literature, the incremental innovations generate incremental gains in cost efficiency. Regarding incremental gains in cost-efficiency that arise from learning-by-doing and ongoing improvements, Gort and Klepper (1982, p.634) state that these changes compresses the profit margins of the less efficient producers who are unable to imitate the leaders. The market shares and profitability of the less efficient firms will fall and may eventually lead to their exit. This is viewed as a slow process that unfolds over many years with only the fittest surviving.

Several papers build on the above theme and provide additional insights; e.g., Klepper and Graddy (1990), Klepper (1996) and Jovanovic and MacDonald (1994). These models assume: (1) a distribution of production efficiencies across the firms; (2) improvements in production efficiency levels due to learning-by-doing and imitation; and (3) a low probability of successful innovations. Each time-period gives rise to opportunities to lower unit production cost and the successful firms enjoy better profit-margins. These improvements in production efficiency result in downward pressure on prices over time. The next step in these models can be thought of an exit from the industry or a process of mergers and acquisitions. Overall, these theories provide an understanding 
of the linkages between the firms' incremental cost-efficiency enhancing activities and profitability; see Audretsch (1995) and Ghosal (2008) for additional discussion of some of these models.

\section{Examining Productivity}

In this section I examine data on productivity for selected multinational firms in this industry. The objective here is not to conduct extensive formal statistical analysis, but simply to take a broad look at the data, examine the patterns and assess the differences across firms.

Table 2 presents the data on capital-labor ratios, labor productivity and stock prices. The table is grouped into two categories of companies: Group A and Group B. It is important to note that most of the companies are large and diversified, producing a variety of paper, packaging, and wood products. In addition, some companies specialize in the production of various tissue papers and consumer hygiene products. Some even produce various types of chemicals. Even within those firms classified as primarily producing pulp and paper, there is variation in terms of basic paper, various types of finished paper, specialty papers such as those for specific types of packaging and tobacco papers, among others. This is not a homogenous group: the companies offer products that are highly differentiated as well as diversified. With this caveat, "Group A" consist of companies that focus more on various types of paper, pulp, some packaging, and related wood products. "Group B" contains a more diverse set of companies that specialize in one or more of the following products: packaging, paperboard, tissues, selected building materials, market pulp, timber products. While some of the companies in Group A produce products common to Group B - e.g., packaging, timber products, etc - they form a "relatively" more comparable group as opposed to those in Group B. Given the size and scope of the companies, it is not possible to create a group of companies that produce only pulp and paper. It is important to note that while there are differences between the 
firms in Group A and Group B, there are significant common papermaking technologies employed by all of the firms in Group A and Group B.

The data are from the Compustat files and selected other sources to obtain data on exchange rates and company stock prices. The summary statistics presented are the mean (standard deviation) from five-years of data over 1994-1998. This period was chosen as it allowed me to get data for most of the firms; using earlier years would have resulted in several companies being dropped from the sample. This period is also a good one as the global markets had emerged from a slowdown and reflected relatively normal to good economic conditions. Of the 27 companies listed in Table 2, 17 are from the US and 5 from Canada. This is largely an artifact of better data availability from the Compustat databases for North American companies. Quite a few of the foreign firms listed in the Compustat Global databases had a significant number of missing observations and therefore could not be used for analysis.

Labor productivity is measured by dividing the company's real sales by the total number of employees on an annual basis. Labor productivity is one of the commonly used measures of firms' cost efficiency with there being a direct relationship between the two: i.e., if a firm's labor productivity is increasing, its unit production cost is falling and cost efficiency is increasing. Multifactor productivity (or total factor productivity, TFP) is a more complete measure, but the Compustat does not provide data (e.g., on materials and energy usage) to compute such a measure. The data for the Group A sample of companies show that labor productivity varies from a low of $\$ 106,000$ per worker to a high of $\$ 186,000$. Looking at column 1 on capital-labor ratios, we observe significant differences across companies. For the companies in Group B, labor productivity varies between a low of $\$ 82,000$ to a high of $\$ 144,000$. As in Group $A$, there is considerable variation in the capitallabor ratio across the companies. The comparisons of the average stock-price over the five-year 
period are illustrative; unfortunately we were not able to obtain historical stock price data for some of the companies.

To get a better perspective, let us first compare three companies: International Paper, Weyerhaueser, and Georgia-Pacific. All three are US companies and have relatively similar profiles. The average labor productivity numbers for the three are $\$ 141,000, \$ 184,000$ and $\$ 171,000$ respectively. The latter two numbers are closer, but labor productivity for International Paper is about $17 \%$ to $23 \%$ lower. Second, consider the following four companies: Norske Skog Canada, Wausau Paper, Badger Paper Mills, and Schweitzer Mauduit. These four are listed as producing only pulp and paper. Therefore, they are relatively more comparable. The labor productivity numbers are $\$ 151,000, \$ 171,000, \$ 123,000$ and $\$ 106,000$, respectively. Again showing considerable variation across firms.

The main point is that the raw data on labor productivity shows considerable differences across relatively comparable companies.

Economic production theory shows that the capital-labor ratio will be an important determinant of labor productivity. The intuition is that if a firm uses more capital per unit of labor, then this company should produce more output per unit of labor. The basic relationship can be seen from a standard Cobb-Douglas production function:

(1) $q_{i}=A_{i} L_{i}^{\alpha} K_{i}^{\beta}$,

where " $\mathrm{i}$ " denotes the firm subscript, $\mathrm{A}$ is an index of the firm's technology, q, L and $\mathrm{K}$ are the firm's output, employment and capital stock. The coefficients $\alpha$ and $\beta$ are the shares of labor and capital in production. A complete specification of the firm's production function would include other 
important inputs the firm uses, such as various materials (wood, chemicals, etc), energy, and services (e.g., transportation of timber logs and finished product). But, as we noted earlier, the Compustat does not provide such detailed data on inputs. For simplicity, let us assume $(\alpha+\beta)=1$, or constant returns-to-scale. Dividing equation (1) throughout by $L$, and using $\beta=(1-\alpha)$ from above and taking natural logarithms (denoted by $\ell n)$ we get:

(2) $\ln \left(\frac{q}{L}\right)_{i}=\ln A_{i}+(1-\alpha) \ln \left(\frac{K}{L}\right)_{i}$,

where $\ell n$ denotes natural logarithm, and the dependent variable is the firm's labor productivity Our data in Table 2 are from a cross-section of firms. To go from (2) to a cross-firm regression we can estimate, we specify: $A_{i}=\left(A+\eta_{i}\right)$, where 'A' reflects the common elements of technology across the firms and $\eta_{i}$ the idiosyncratic, firm-specific, component. The cross-firm regression we estimate using the data presented in Table 2 is given by:

(3) $\ln \left(\frac{q}{L}\right)_{i}=\ln A+(1-\alpha) \ln \left(\frac{K}{L}\right)_{i}+\varepsilon_{i}$.

In (3), $\varepsilon_{\mathrm{i}}$ is the firm-specific regression error, where: $\varepsilon_{i}=\left(v_{i}+\eta_{i}\right)$. As noted before, $\eta_{\mathrm{i}}$ is the firmspecific idiosyncratic component of technology, and $v_{\mathrm{i}}$ includes any other omitted (from the regression) factors that influence the firm's labor-productivity.

It is quite obvious that the number of observations in Table 2 is low, and this is a limitation. However, we note that the firms in our sample are "relatively" similar in the sense that most of them use very similar production technologies, equipment and machinery, timber and chemicals in the 
production process, and are highly energy-intensive. In short, we do not have large heterogeneity in our sample as would be the case if it included Microsoft, Toyota, Johnson \& Johnson, and International Paper. In this sense, our smaller sample size is relatively less of a handicap.

To be clear, I present these results to take a quick look at the data. Using the data presented in Table 2, we present estimates from specification (5). This regression will reveal how much of the difference in labor-productivity across the firms will remain after we control for the capital-labor ratio, arguably one of the most important determinants. The estimated equation using the Group A sample is (standard errors in parentheses):

(4) $\ln \left(\frac{q}{L}\right)_{i}=\underset{(0.468)}{3.657}+\underset{(0.096)}{0.267} \ln \left(\frac{K}{L}\right)_{i} \quad \bar{R}^{2}=0.2931 \quad N=17$,

and the estimated equation using both Group A and Group B data is:

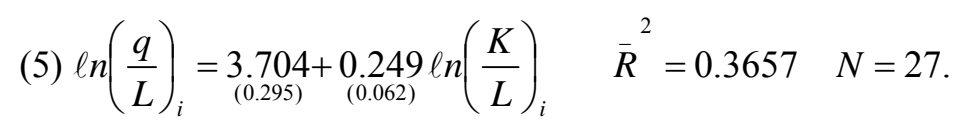

Given the standard errors, the estimated coefficients are statistically the same for the two regressions. As expected, this signals that many of the underlying technological relationships are similar across these firms. Since the equation is estimated in log-linear form, the estimate on $(K / L)$ is the elasticity: it indicates that a $10 \%$ increase in the capital-labor ratio leads to approximately a $2.5 \%$ increase in the firm's labor-productivity. The regressions - using the adjusted- $\mathrm{R}^{2}$ values - explain less than $40 \%$ of the variation in labor-productivity across this sample of firms. This implies that more than $60 \%$ of the variation in labor productivity across the firms in our sample remains unexplained by the above baseline regression which is derived from standard economic production theory. Some of this is due to the idiosyncratic technological and cost-efficiency differences across 
the firms as captured by $\eta_{\mathrm{i}}$ in the error term. The balance is due to the effect of omitted variables, as captured by $v_{\mathrm{i}}$ in the error term. Unfortunately, the Compustat database does not contain detailed information on the firms' other important inputs such as materials and energy, which would be needed for a thorough examination.

To provide a glimpse of some of the other factors, Ghosal and Nair-Reichert (2009) examine the impact of the firms' investments in mechanical, digital and chemicals area on their labor productivity. The results in this paper, for example, reveal that: ${ }^{8}$

- A firm that has a one-standard-deviation larger number of investment transactions in the "Mechanical" category (relative to the mean number of such transactions across firms) has $\$ 13,450$ higher labor productivity. The mechanical category includes any investment in mechanical equipment and machinery (but not ICT).

- A firm that has a one-standard-deviation larger number of investment transactions in the "Digital" category (relative to the mean number of such transactions across firms) has $\$ 15,520$ higher labor productivity. The digital category includes investments in digital recording, monitoring and quality control devices, and software.

An important conclusion from that paper is that these (modernization) investments meaningfully add to firm-level productivity and help explain some of the observed differences in efficiency across firms.

Finally, Figures 1a-1d display the time-series data on labor productivity for some of the firms noted in table 2. Figure 1a contains data for three of the bigger US firms, Figure 1b on some other US firms, and Figures 1c and 1d on selected Canadian and Scandinavian firms. These data

\footnotetext{
${ }^{8}$ For convenience, I reproduce the table of estimates from that paper as Table $\mathbf{3}$ in this paper.
} 
show that:

- Not only are there productivity differences across firms, the differences seem somewhat persistent over the sample period. Consider, for example, the differences between International Paper and Georgia Pacific (in Fig 1a), and UPM-Kymmene and Stora Enso (in Fig 1d).

- There are interesting intertemporal movements (convergence and divergence) of labor productivity as we compare across firms. Consider, for example, the productivity paths between Norske Skog Canada and Abitibi (in Fig 1c), and between Weyerhauser and International Paper (in Fig 1a).

Overall, keeping the data limitations and the small number of observations in mind, the data in Table 2 - whether we eyeball it or conduct some simple statistical analysis - and Figures 1a-1d point to significant differences in the levels labor productivity (and, consequently, cost efficiency) across the firms in this industry, as well as important differences in the intertemporal dimension.

\section{Insights from the Strategic Management Literature}

What factors might lead to the observed differences in labor productivity across the sample of firms in Table 2? There are alternative streams of thought in the Resource Based View literature regarding whether differences across firms - in measures of productivity, performance, etc - can exist and persist. Denrell, Fang and Winter (2003), Dierickx and Cool (1989) and Zott (2003), for example, present a convincing set of arguments that firms are presented with a range of potential strategic opportunities by which they can distance themselves from their rivals, that idiosyncratic non-tradable assets exist and are important, and differences can occur and persist across firms.

Denrell, Fang and Winter (2003) argue that a crucial missing element in the resource 
valuation story are the "idiosyncratic information and capabilities" of an individual firm. They note:

"in a changing environment, there is continuing renewal of each firm's view of the opportunities that are differentially suited to it, even without explicit effort to this end by the firm itself. Whether the opportunities seen are actually seized is, however, an important question. We argue that the discovery of a valuable strategic opportunity is often a matter of 'serendipity' in the strict sense - not just luck, but effort and luck joined by alertness and flexibility." "The range of things that have not been tried is simply too vast. If some areas are mined out, while in others the valuable claims are carefully staked and guarded, it is not because there is no virgin territory to search. It is because the searchers stay within the fences of their ideas, particularly their shared ideas." "When a firm has assembled many of the necessary resource components, it may be able to see that these resources could be valuable if complemented with some others. As a result, the search for the last components will be intentional rather than serendipitous."

The arguments presented by Dierickx and Cool (1989) lend credence to the view that there exists a class of non-appropriable resources whose values are difficult to identify and could give rise to a set of strategic opportunities. They discuss the role of "resource bundles" which need to be recognized and deployed to achieve or protect a firm's market position. They note that "managers often fail to recognize that a bundle of assets, rather than the particular product market combination chosen for its deployment, lies at the heart of their firm's competitive position.” Teece, Pisano and Shuen (1997) note that the competitive advantage of firms may rest on distinctive processes such as ways of coordinating and combining, shaped by firm-specific assets such as the firm's portfolio of difficult-to-trade knowledge assets and complementary assets. These could be highly idiosyncratic knowledge that firms acquire via internal learning-by-doing which other forms may find hard to imitate.

In the context of our study, the notions of the accumulation of "strategic asset stocks" as well as the "interconnectedness of asset stocks" could be particularly important in understanding differences across firms in the pulp and paper industry. As noted in section 2 , the major technologies in the pulp and paper industry (e.g., paper making machine, bleaching, drying, collandering and 
other units) are, in principle, accessible to all the firms. The production process itself is very complicated and requires a high level of engineering knowledge and understanding of each of its components as well as how the different components fit together. Supply-chain management is very important in making sure that the paper mill gets the right inputs, of the right quality and at the right time. My experiences in talking with mill managers and industry consultants revealed that there is a continuous attempt - at least by some firms - to try and figure out how to tweak various combinations in the production process to coax additional cost-efficiencies. While some of this may (eventually) be known and imitated by particular players in the industry, some of it inevitably is unique to each firm. This stock of knowledge incrementally builds up and, in the longer-run, may present a firm with unique opportunities to be more efficient and profitable. To those who say that since the processes and products in this industry are relatively well known, how can one firm gain an advantage over others? The answer, in part, lies at the range of possibilities that potentially exist. In the words of Denrell, Fang and Winter: "the range of things that have not been tried is simply too vast."

The other insight provided in the strategy literature comes from the work of Zott (2003). The central question Zott seeks to answer is: "Why do firms in the same industry perform differently?" In a sense, this question goes to the heart of what we are attempting to figure out in this paper, and the data in Table 2 and Figures 1a-1d clearly reveal stark differences. After a lucid review of the literature, Zott formulates three central propositions:

Proposition 1: Differential timing of resource deployment fosters the emergence of intraindustry differential firm performance.

Proposition 2: Differential costs, associated with the deployment of resources, foster the emergence of intra-industry differential firm performance. 
Proposition 3: Learning how to deploy resources, both directly and indirectly, fosters the emergence of intra-industry differential firm performance.

If we combine the insights of Denrell, Fang and Winter (2003), Dierickx and Cool (1989) and Zott (2003), one could argue that given a potentially large range of possibilities for improvement that are idiosyncratic to the firms, and the effect of timing, cost and implementation of changes, there could emerge meaningful differences across firms even within a relatively well-defined industry, with the main players making similar products, and having access to the same core set of technologies and resources. When faced with changing market conditions, some of the key ingredients for maintaining or enhancing the firm's competitive advantage would appear to be knowledge of the changes, ability to forecast the new direction of the markets, knowledge of the internal processes, and implementing a set of optimal solutions in a timely manner.

Overall, the significant differences in productivity we observed across the firms in Table 2, tie in to the insights of Denrell, Fang and Winter (2003) and Zott (2003) that there may be numerous idiosyncratic firm-specific considerations that may result in intra-industry differences in productivity and performance across firms.

\section{Market Conditions, Organizational Behavior, and Insights for Managers}

My inferences from the visits to the paper mills and some of the data-based analysis reveal considerable differences across firms in the dimensions of productivity and performance. The big question is: Why might these differences arise? Below are some insights.

(1) There appear to be differences between the firms in their focus, knowledge about the complementarities among various aspects of the production process and supply-chain management, perceptions about the changes in the markets, emphasis on the long-run versus shorter-run, and 
extent of organizational changes made.

(2) There appears to be differences across firms in their knowledge and their ability to made incremental changes to the production processes and supply-chain to generate gains in production efficiency. This appears to be a central finding of our analysis, and links the issues of knowledge about processes, complementarities in various aspects of the firms resources, timing of changes made, and the ability to maintain and gain an advantage compared to one's rivals.

(3) The more consistent and stringent environment pollution control standards in Northern Europe and Scandinavia appear to have helped some of the European companies. The combination of strict, but transparent, standards and the economic downturn during the 1987-1993 period, lead to some European companies to implement a significant array of changes. Even among European companies, there are differences between the extent and types of changes made. It appears that knowledge of the inter-linkages between the public policy rules and regulations and emerging market conditions vary across the firms.

(4) There appears to be a perception that the nature of U.S. stock markets, at least at the margin, hinder large new investments, and investments in modernization in this industry. In part this seems to be related to the observation that in Europe, a larger fraction of stocks are held by large institutions and banks who may have a somewhat longer-run view of the markets, allowing firms to make costly, but necessary, investments. ${ }^{9}$

Finally, we end with a big picture perspective on organizational behavior and change. One

\footnotetext{
${ }^{9}$ These sentiments are echoed in: (1) the acquisition of Georgia-Pacific by the Koch group, and (2) Financial Times (June 26, 2007): "Quarterly guidance is at best a waste of resources and, more likely, a self-fulfilling exercise that attracts short-term traders," says the report by the group, which was brought together by the Committee for Economic Development, a Washington think-tank. "A week ago, another coalition, masterminded by the Aspen Institute, issued a similar warning, saying US economic competitiveness was being harmed by companies' near-term focus. That warning, first reported in the FT, echoed the concerns expressed by other groups of academics and business people, including one backed by Hank Paulson, Treasury secretary, in the past few months."
} 
particular issue in the spotlight is the significance of incremental efficiency gains, and there appears to be differences across firms in terms of how much they focus on this. To put matters in perspective, think of a typical paper-making machine used by some of the larger firms. The machine could be capable of producing about 800,000 tons of paper per year. This translates to about 2,192 tons per day, or 91 tons per hour, or about 1.5 tons of paper per minute. This is a lot of paper. What this means is that errors in the production process (that may result in a bad batch of paper) are costly. First, an error implies a waste of inputs (chemicals, wood, energy, etc) that was used to produce the paper. Second, production of the paper resulted in environmental waste which needs to be cleaned up. Third, the paper that could not be used will now have to be recycled. All of this implies a very high premium for reducing errors. Investments in ICT (such as digital cameras, monitoring and recording systems that are centrally controlled) and the resulting changes in the firms' organization structure (making it less hierarchial and giving the appropriate operations personnel the powers to alter the speed of the production process and make timely decisions) can provide significant costsavings to the firms. These ICT and related modernization investments need to be done in a timely manner, along with an extreme focus on tweaking out incremental efficiency gains. My observations on the broader role of ICT and organizational factors are consistent with those in the literature: e.g., Bresnahan, Brynjolfsson and Hitt (2002) and Brynjolfsson, Hitt and Yang (2002).

\section{Assessing Innovative Activity in Traditional Industries}

In this final section, I discuss some of the complexities of measuring innovative activity in traditional industries such as pulp and paper.

Let us first examine some of the standard measures such as R\&D expenditures and patents. If 
we consider four of the largest firms - International Paper, Stora Enso, UPM Kymmene and Weyerhaeuser - their R\&D intensity averaged approximately $0.4 \%$. For the pulp and paper industry as a whole, the $R \& D$ intensity is approximately $0.6-0.7 \%$ Compare this to the following sector average R\&D intensities: electrical and electronics 4-5\%; Industrial engineering 2-3\%; and software and computer services $10-11 \%$. Another comparison is to Toyota in the automobile industry with a $3.5-4 \% \mathrm{R} \& \mathrm{D}$ intensity. In the manufacturing sector, pulp and paper has one of the lowest $\mathrm{R} \& \mathrm{D}$ intensities. In terms of total patent counts, the typical firm in this industry is associated with an average of 2-3 patents per year. Therefore, both patenting activity and R\&D-intensity is low in this industry. Finally, as noted in Ghosal and Nair-Reichert (2009), inclusion of R\&D and patents data in the estimated productivity equations (such as those reported in table 3 ) did not reveal any additional insights. This was mainly due to the very low levels of R\&D intensities and typically low patent counts.

Part of this lack of innovation, as captured by the standard measures, relates to the fact that the industry is one of the most capital-intensive in manufacturing, and most of the technological advances are embedded in the machinery and equipment that the paper firms purchase from suppliers. This includes the main papermaking machine.

My visits to the paper mills in the four countries revealed that one needs to think more broadly about innovative activities in these types of traditional industries than simply focus on the standard measures related to R\&D intensity and patents.

First, would be to measure the fraction of workers who have degrees in science and engineering. The production managers I talked to noted that they have a highly skilled workforce (in the sense that they have technical backgrounds). These workers, while not officially listed as R\&D workers (as is the case in many industries), are responsible for examining the production processes 
and suggesting changes that would improve the functioning of the processes, enhance the efficiency of operations and deliver cost-savings.

Second, many of the changes made by the firms related to changes in the organizational structure (such as changing the hierarchial decision-making structure) and restructuring of contracts in supply-chains and transportation. Some of these were detailed in section 4. Across all of my mill trips, the mill managers viewed these as crucial to improving efficiency of operations and staying competitive in a tough market. With this in mind, it would be useful to think about innovations in organizational structure and contractual relationships. Obtaining data on these will undoubtedly be difficult, but detailed firm-specific studies can provide key insights. 


\section{References}

Audretsch D. 1995. Innovation and Industry Evolution. Cambridge: MIT Press.

Barsky J. 1999. Forest industry harvests a green future: voluntary investments in technology are setting environmental example. News World Communications, Inc.

Bjorkman A, Paun D, Jacobs-Young C. 1997. Financial performance, capital expenditures, and international activities of the North American pulp and paper industry at mid-decade. The TAPPI Journal 80: 71-84.

Bresnahan T, Brynjolfsson E, Hitt LM. 2002. Information Technology, Workplace Organization, and the Demand for Skilled Labor: Firm-Level Evidence, Quarterly Journal of Economics 117, 339-376.

Brynjolfsson E, Hitt L, Yang S. 2002. Intangible Assets: Computers and Organizational Capital," Brookings Papers on Economic Activity.

Denrell J, Fang C, Winter SG. 2003. The economics of strategic opportunity. Strategic Management Journal 24: 977-990.

Dierickx I, Cool KO. 1989. Asset stock accumulation and sustainability of competitive advantage. Management Science 35, 1504-1511.

Dixit A. 1980. The role of investment in entry deterrence. Economic Journal 9: 95-106.

Drucker P. 1995. Managing in a Time of Change. Truman Talley: New York.

Ghosal V. 2002. Potential foreign competition in U.S. manufacturing. International Journal of Industrial Organization 20: 1461-1489.

Ghosal, V. 2008. Small is Beautiful but Size Matters: The Asymmetric Impact of Uncertainty and Sunk Costs on Small and Large Businesses. Georgia Institute of Technology.

Ghosal V, Nair-Reichert U. 2009. Investments in modernization, innovation and gains in productivity: evidence from firms in the global paper industry. Research Policy, 2009, 536-547.

Gort M, Klepper S. 1982. Time paths in the diffusion of product innovations. Economic Journal 92: 630-653.

Harrison K. 2002. Ideas and environmental standard setting: a comparative study of regulation in the pulp and paper industry. Governance: An International Journal of Policy, Administration and Institutions 15: 69-96.

Ince PJ. 1999. Global cycle changes the rules for U.S. pulp and paper. Industry Review. Jovanovic B, MacDonald G. 1994. “The Life Cycle of a Competitive Industry,” Journal of Political 
Economy, 322-347.

Klepper S. 1996. "Entry, Exit, Growth, and Innovation over the Product Life Cycle," American Economic Review 86, 562-583.

Klepper S, Graddy E. 1990. "The Evolution of New Industries and the Determinants of Market Structure," The RAND Journal of Economics 21, 27-44.

Li H, McCarthy P, Urmanbetova A. 2004. Containerboard industry review: 1970-2000. Center for Paper Business and Industry Studies.

McNutt James. 2002. The paper industry. Presentation at the Sloan workshop on globalization.

Norberg-Bohm V, Rossi M. 1998. Power of incrementalism: environmental regulation and technological change in pulp and paper beaching in the U.S. Technology Analysis and Strategic Management 10: 225-45.

Pesendorfer M. 2003. Horizontal mergers in the paper industry. RAND Journal of Economics 34: 495-515.

Pulp and Paper North American Factbook. 2001. Paperloop Publications.

Spender JC, Grant R. 1996. Knowledge and the firm: overview. Strategic Management Journal, Winter Special Issue 17: 5-9.

Teece DJ, Pisano G, Sheen A. 1997. Dynamic capabilities and strategic management. Strategic Management Journal 18: 509-533.

Zott C. 2003. Dynamic capabilities and the emergence of intra-industry differential firm performance: insights from a simulation study. Strategic Management Journal 24: 97-125. 


\section{Table 1. Real GDP growth (\%) by region}

\begin{tabular}{|r|r|r|r|}
\hline \multicolumn{1}{l|}{ Year } & \multicolumn{1}{|l|}{ World } & \multicolumn{1}{l|}{$\begin{array}{l}\text { North } \\
\text { America }\end{array}$} & \multicolumn{1}{l|}{ EU 25 } \\
\hline 1987 & 3.37 & 3.39 & 2.84 \\
\hline 1988 & 3.68 & 3.44 & 2.78 \\
\hline 1989 & 4.55 & 4.19 & 4.10 \\
\hline 1990 & 3.68 & 3.47 & 3.29 \\
\hline 1991 & 2.81 & 1.76 & 2.33 \\
\hline 1992 & 1.45 & -0.31 & 0.61 \\
\hline 1993 & 2.11 & 3.15 & 0.84 \\
\hline 1994 & 1.79 & 2.65 & -0.19 \\
\hline 1995 & 3.26 & 4.07 & 2.98 \\
\hline 1996 & 2.90 & 2.52 & 2.79 \\
\hline 1997 & 3.36 & 3.56 & 1.88 \\
\hline 1998 & 3.70 & 4.48 & 2.72 \\
\hline
\end{tabular}

Note: Data are from the World Bank statistical tables. 


\section{Table 2. Selected firm-specific variables Time-period: 1994-1998}

\begin{tabular}{|c|c|c|c|c|}
\hline Company & Country & $\begin{array}{l}\text { Capital- } \\
\text { labor ratio }\end{array}$ & $\begin{array}{l}\text { Labor } \\
\text { productivity }\end{array}$ & Stock price \\
\hline \multicolumn{5}{|l|}{ A. Mainly paper, pulp and related } \\
\hline 1. International Paper (paper, pulp, packaging, forest products) & USA & $105(9)$ & $141(3)$ & $41(4)$ \\
\hline 2. Weyerhaueser (paper, pulp, packaging) & USA & $130(8)$ & $184(8)$ & $46(3)$ \\
\hline 3. Georgia-Pacific (paper, pulp, wood products, chemicals) & USA & $90(7)$ & $171(6)$ & $36(5)$ \\
\hline 4. Willamette (white paper, brown paper, building materials) & USA & $152(22)$ & $163(8)$ & $30(4)$ \\
\hline 5. Stora Enso (paper, pulp, packaging, wood products) 4.71 & Finland & $175(9)$ & $179(10)$ & NA \\
\hline 6. UPM Kymmene (paper, pulp, packaging, wood products) & Finland & $133(12)$ & $159(13)$ & $17(2)$ \\
\hline 7. Norske Skog Canada (paper, pulp) & Canada & $277(51)$ & $151(14)$ & $\mathrm{NA}$ \\
\hline 8. Wausau Paper (paper, pulp) & USA & $105(8)$ & $171(7)$ & $19(1)$ \\
\hline 9. Longview Fibre (paper, pulp, packaging, wood products) & USA & $148(8)$ & $130(14)$ & $16(2)$ \\
\hline 10. Badger Paper Mills (paper, pulp) & USA & $47(5)$ & $123(8)$ & $11(3)$ \\
\hline 11. Abitibi (paper, pulp, wood products) & Canada & $75(19)$ & $101(23)$ & $30(13)$ \\
\hline 12. Bowater (paper, pulp, wood products) & USA & $235(6)$ & $186(35)$ & $38(8)$ \\
\hline 13. Schweitzer Mauduit (paper, pulp)* & USA & $46(5)$ & $106(11)$ & $23(9)$ \\
\hline 14. Domtar (paper, pulp, wood products) & Canada & $82(4)$ & $80(16)$ & $7(1)$ \\
\hline 15. Tembec (paper, pulp, packaging, wood products) & Canada & $185(21)$ & $116(6)$ & NA \\
\hline 16. Glatfelter (paper, pulp, composite laminates) & USA & $94(7)$ & $112(6)$ & $17(2)$ \\
\hline 17. Holmen (paper, packaging, timber products) & Sweden & $296(21)$ & $180(12)$ & NA \\
\hline \multicolumn{5}{|l|}{ B. Others } \\
\hline 1. Kimberly Clark (tissues and related) & USA & $65(6)$ & $132(13)$ & $40(10)$ \\
\hline 2. Caraustar Industries (paperboard, packaging) & USA & $34(5)$ & $85(2)$ & $25(5)$ \\
\hline 3. Aracruz Celulose (market pulp)* & Brazil & $380(38)$ & $120(24)$ & $12(4)$ \\
\hline 4. Smurfit-Stone (packaging, corrugated containers) & USA & $70(11)$ & $115(36)$ & $15(2)$ \\
\hline 5. Svenska Celulosa (tissue, packaging, pulp, forest products) & Sweden & $99(9)$ & $144(18)$ & $23(1)$ \\
\hline 6. MeadWestvaco (packaging, paper, chemicals) & USA & $150(17)$ & $136(9)$ & $28(3)$ \\
\hline 7. Potlatch (packaging, wood products) & USA & $160(4)$ & $139(4)$ & $42(2)$ \\
\hline 8. Rock-Tenn (packaging, paperboard) & USA & $33(5)$ & $82(4)$ & $16(2)$ \\
\hline 9. Temple-Inland (packaging, building) & USA & $112(4)$ & $135(7)$ & $51(6)$ \\
\hline 10. Cascades (packaging, tissue, paper, molded pl & Canada & $80(12)$ & $99(18)$ & $8(2)$ \\
\hline
\end{tabular}

Notes:

1. The data are from Compustat. NA denotes that data were not available.

2. The numbers are the mean (standard deviation) for each variable for each firm over the 1994-1998 period.

3. Group A consist of 17 companies (in no particular order) that mainly produce various types of paper, pulp, some packaging, and related wood products. Group B contains a more diverse set of 10 companies (in no particular order) that specialize in one or more of the following products: packaging, paperboard, tissues, selected building materials, market pulp, timber products. While some of the companies in Group A produce products common to Group B companies - e.g., packaging, timber products, etc - they form a "relatively" more homogenous group compared to the companies in Group B. Given the business and product lines of the companies in Group A, it is not possible difficult to create a group of companies that produce only pulp and paper.

4. Variables:

Capital-labor ratio $=$ real capital (plant, property and equipment) divided by total employees

Labor productivity $=$ real sales divided by total employees

5. Comments on firms labeled with a *: data for Schweitzer Mauduit are from 1995-1998; data for Aracruz Celulose are from 1994-1996. 


\begin{tabular}{|c|c|c|c|c|}
\hline & A & B & $\mathbf{C}$ & D \\
\hline 1. $(\mathrm{K} / \mathrm{L})$ & $\begin{array}{r}26.97^{*} \\
(8.01) \\
\end{array}$ & $\begin{array}{r}27.86^{*} \\
(8.33)\end{array}$ & $\begin{aligned} 26.94^{*} \\
(7.17)\end{aligned}$ & $\begin{aligned} 29.64 * \\
(8.79)\end{aligned}$ \\
\hline 2. Patents & $\begin{array}{l}9.01^{*} \\
(3.08) \\
\end{array}$ & $\begin{array}{l}9.58^{*} \\
(2.90)\end{array}$ & $\begin{array}{l}6.20^{*} \\
(2.78) \\
\end{array}$ & $\begin{array}{r}5.07 \\
(1.45) \\
\end{array}$ \\
\hline 3. Mergers: Total & $\begin{array}{r}-5.45 \\
(-1.03) \\
\end{array}$ & $\begin{array}{r}-4.99 \\
(-0.90) \\
\end{array}$ & $\begin{array}{r}-2.72 \\
(-0.65) \\
\end{array}$ & $\begin{array}{r}-1.36 \\
(0.33) \\
\end{array}$ \\
\hline $\begin{array}{l}\text { 4. Total } \\
\text { Investment Transactions }\end{array}$ & $\begin{array}{r}15.10^{*} \\
(3.98) \\
\end{array}$ & - & - & - \\
\hline $\begin{array}{l}\text { 5. Mechanical } \\
\text { Investment Transactions }\end{array}$ & - & $\begin{aligned} 13.45 * \\
(2.82)\end{aligned}$ & - & - \\
\hline $\begin{array}{l}\text { 6. Digital } \\
\text { Investment Transactions }\end{array}$ & - & - & $\begin{array}{r}15.52 * \\
(4.09) \\
\end{array}$ & - \\
\hline $\begin{array}{l}\text { 7. Chemical } \\
\text { Investment Transactions }\end{array}$ & - & - & - & $\begin{array}{r}4.01 \\
(0.65)\end{array}$ \\
\hline $\begin{array}{l}\text { \# Observations } \\
\text { Adjusted-R }\end{array}$ & $\begin{array}{r}19 \\
0.7961 \\
\end{array}$ & $\begin{array}{r}19 \\
0.7657 \\
\end{array}$ & $\begin{array}{r}19 \\
0.8072 \\
\end{array}$ & $\begin{array}{r}19 \\
0.6476 \\
\end{array}$ \\
\hline
\end{tabular}

Notes:

1. These estimates are from Ghosal and Nair-Reichert (2009). The sample of firms used to obtain the estimates in this table are different from the sample of firms presented in Table 2. The 'investment transactions' variables are defined as follows: row 4 shows the total number of investment transactions; row 5 the number of investment transactions classified as mechanical; row 6 are transactions in the digital category (this includes ICT, digital recording devices, etc); and row 7 are transaction sin the chemical category.

2. Patents and mergers are not measured in logarithms. All other variables are measured in logarithms.

3. $t$-statistics computed from heteroscedasticity-consistent standard-errors are in parentheses. An asterisk * denotes statistical significance at least at the $10 \%$ level. 

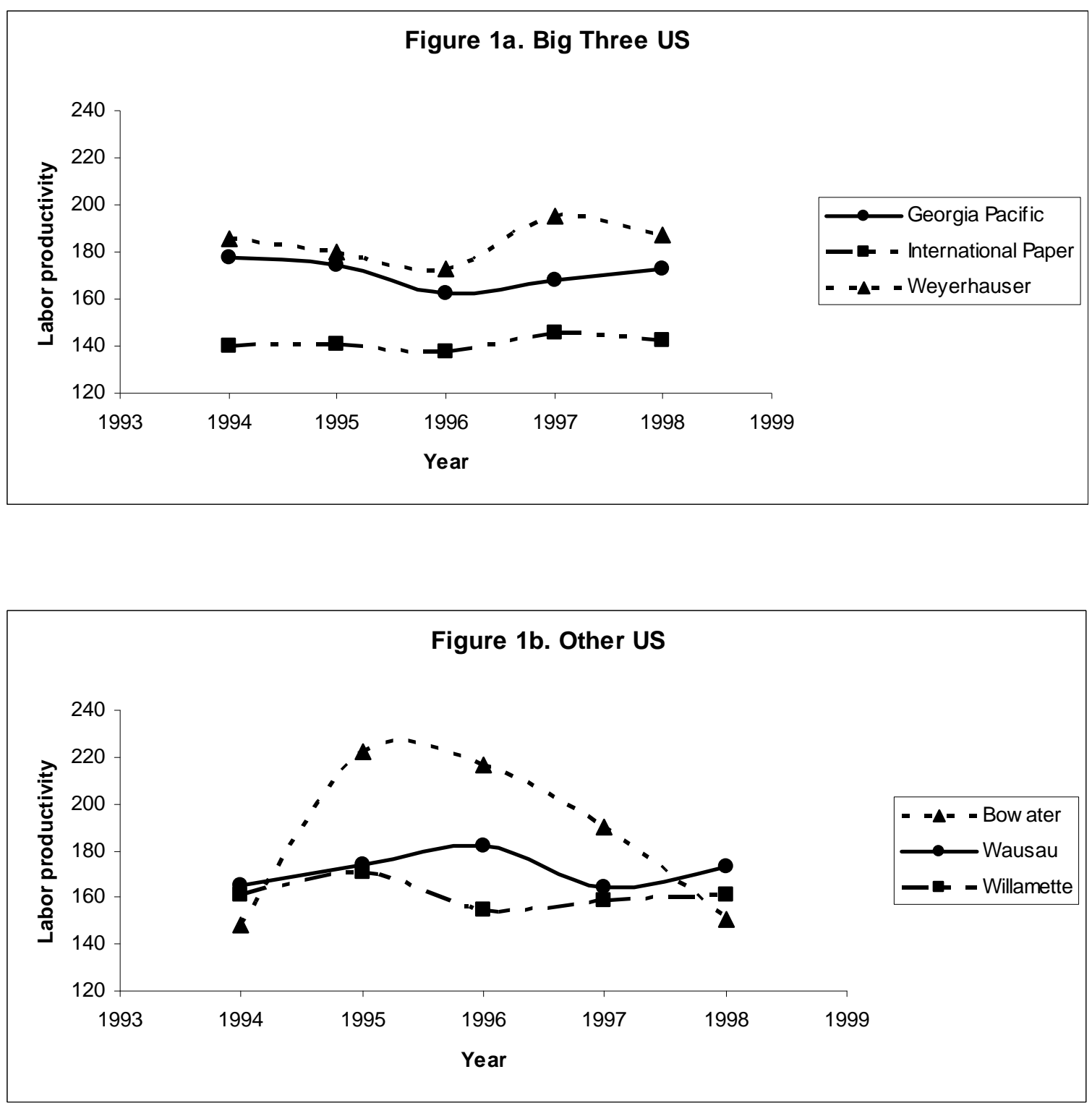

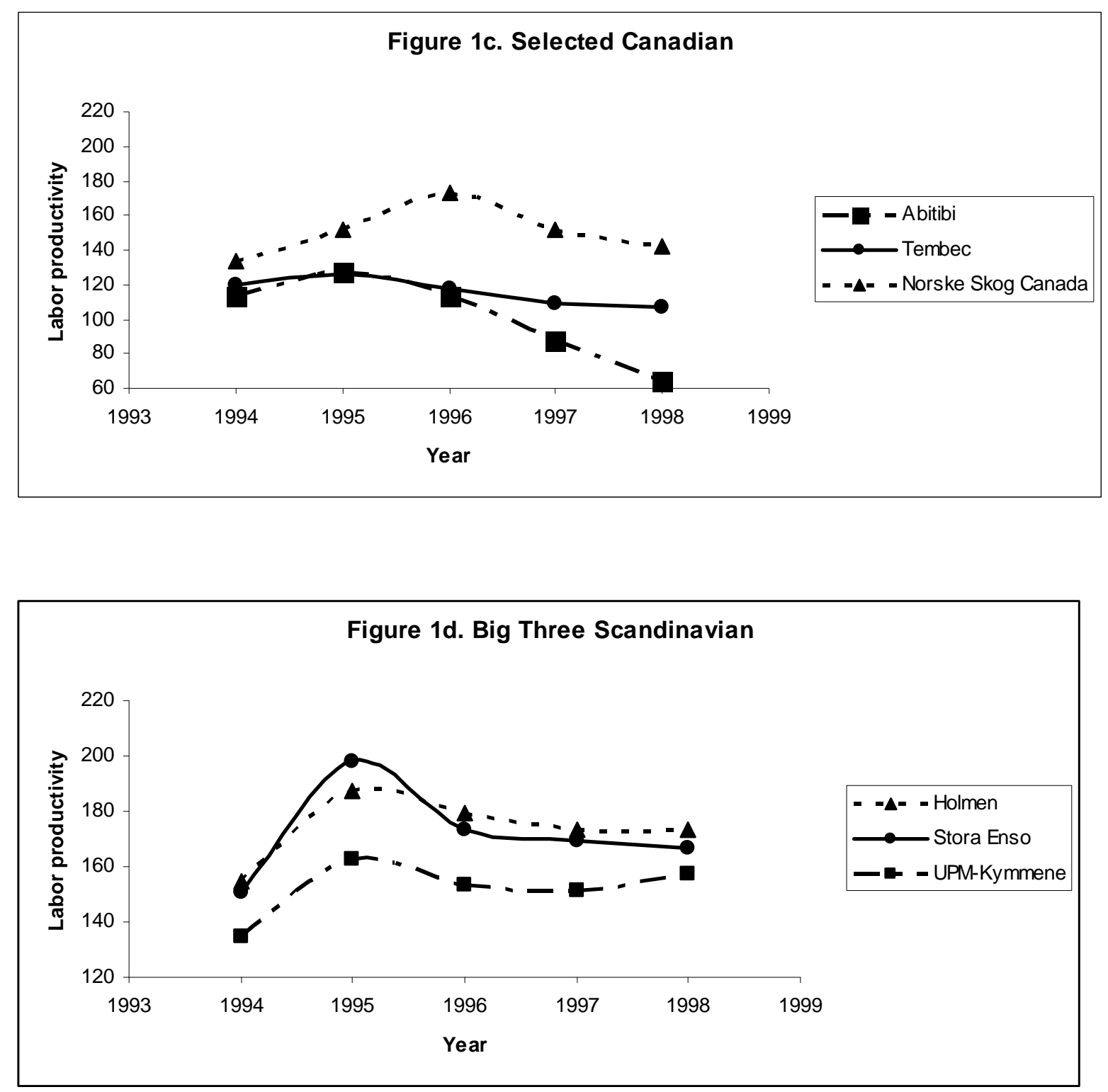


\section{CESifo Working Paper Series}

for full list see www.cesifo-group.org/wp

(address: Poschingerstr. 5, 81679 Munich, Germany, office@cesifo.de)

2613 Michael Melvin, Christian Saborowski, Michael Sager and Mark P. Taylor, Bank of England Interest Rate Announcements and the Foreign Exchange Market, April 2009

2614 Marie-Louise Leroux, Pierre Pestieau and Gregory Ponthiere, Should we Subsidize Longevity?, April 2009

2615 Ronald MacDonald, Lukas Menkhoff and Rafael R. Rebitzky, Exchange Rate Forecasters’ Performance: Evidence of Skill?, April 2009

2616 Frederick van der Ploeg and Steven Poelhekke, The Volatility Curse: Revisiting the Paradox of Plenty, April 2009

2617 Axel Dreher, Peter Nunnenkamp, Hannes Öhler and Johannes Weisser, Acting Autonomously or Mimicking the State and Peers? A Panel Tobit Analysis of Financial Dependence and Aid Allocation by Swiss NGOs, April 2009

2618 Guglielmo Maria Caporale, Roman Matousek and Chris Stewart, Rating Assignments: Lessons from International Banks, April 2009

2619 Paul Belleflamme and Martin Peitz, Asymmetric Information and Overinvestment in Quality, April 2009

2620 Thomas Dohmen, Armin Falk, David Huffman and Uwe Sunde, Are Risk Aversion and Impatience Related to Cognitive Ability?, April 2009

2621 Yin-Wong Cheung and Xingwang Qian, The Empirics of China's Outward Direct Investment, April 2009

2622 Frédérique Bec and Christian Gollier, Assets Returns Volatility and Investment Horizon: The French Case, April 2009

2623 Ronnie Schöb and Marcel Thum, Asymmetric Information Renders Minimum Wages Less Harmful, April 2009

2624 Martin Ruf and Alfons J. Weichenrieder, The Taxation of Passive Foreign Investment Lessons from German Experience, April 2009

2625 Yao Li, Borders and Distance in Knowledge Spillovers: Dying over Time or Dying with Age? - Evidence from Patent Citations, April 2009

2626 Jim Malley and Ulrich Woitek, Technology Shocks and Aggregate Fluctuations in an Estimated Hybrid RBC Model, April 2009

2627 Jin Cao and Gerhard Illing, Endogenous Systemic Liquidity Risk, April 2009 
2628 Thiess Buettner and Bjoern Kauder, Revenue Forecasting Practices: Differences across Countries and Consequences for Forecasting Performance, April 2009

2629 Håkan Selin, The Rise in Female Employment and the Role of Tax Incentives - An Empirical Analysis of the Swedish Individual Tax Reform of 1971, April 2009

2630 Nick Johnstone and Ivan Hascic, Environmental Policy Design and the Fragmentation of International Markets for Innovation, April 2009

2631 Spiros Bougheas, Richard Kneller and Raymond Riezman, Optimal Education Policies and Comparative Advantage, April 2009

2632 Jay Pil Choi and Heiko Gerlach, Multi-Market Collusion with Demand Linkages and Antitrust Enforcement, April 2009

2633 Thor O. Thoresen, Income Mobility of Owners of Small Businesses when Boundaries between Occupations are Vague, April 2009

2634 Guido Schwerdt and Amelie C. Wuppermann, Is Traditional Teaching really all that Bad? A Within-Student Between-Subject Approach, April 2009

2635 Kurt R. Brekke, Luigi Siciliani and Odd Rune Straume, Hospital Competition and Quality with Regulated Prices, April 2009

2636 Peter Diamond, Taxes and Pensions, April 2009

2637 Shoshana Grossbard, How “Chicagoan” are Gary Becker’s Economic Models of Marriage?, May 2009

2638 Roland Strausz, Regulatory Risk under Optimal Incentive Regulation, May 2009

2639 Holger Zemanek, Ansgar Belke and Gunther Schnabl, Current Account Imbalances and Structural Adjustment in the Euro Area: How to Rebalance Competitiveness, May 2009

2640 Harald Hau and Marcel Thum, Subprime Crisis and Board (In-)Competence: Private vs. Public Banks in Germany, May 2009

2641 Martin Halla, Mario Lackner and Friedrich G. Schneider, An Empirical Analysis of the Dynamics of the Welfare State: The Case of Benefit Morale, May 2009

2642 Balázs Égert, Infrastructure Investment in Network Industries: The Role of Incentive Regulation and Regulatory Independence, May 2009

2643 Christian Gollier, Expected Net Present Value, Expected Net Future Value, and the Ramsey Rule, May 2009

2644 Sören Blomquist and Håkan Selin, Hourly Wage Rate and Taxable Labor Income Responsiveness to Changes in Marginal Tax Rates, May 2009 
2645 Dominique Demougin, Oliver Fabel and Christian Thomann, Implicit vs. Explicit Incentives: Theory and a Case Study, May 2009

2646 Francesco C. Billari and Vincenzo Galasso, What Explains Fertility? Evidence from Italian Pension Reforms, May 2009

2647 Kjell Arne Brekke, Karen Evelyn Hauge, Jo Thori Lind and Karine Nyborg, Playing with the Good Guys - A Public Good Game with Endogenous Group Formation, May 2009

2648 Guglielmo Maria Caporale and Luis A. Gil-Alana, Multi-Factor Gegenbauer Processes and European Inflation Rates, May 2009

2649 Henning Bohn, A Static Model for Voting on Social Security, May 2009

2650 Markus Haavio and Kaisa Kotakorpi, The Political Economy of Sin Taxes, May 2009

2651 Augusto de la Torre, María Soledad Martínez Pería and Sergio L. Schmukler, Drivers and Obstacles to Banking SMEs: The Role of Competition and the Institutional Framework, May 2009

2652 Tobias Lindhe and Jan Södersten, Dividend Taxation, Share Repurchases and the Equity Trap, May 2009

2653 Assaf Razin and Edith Sand, Migration-Regime Liberalization and Social Security: Political-Economy Effect, May 2009

2654 Yin-Wong Cheung and Hiro Ito, A Cross-Country Empirical Analysis of International Reserves, May 2009

2655 Bart Cockx and Bruno Van der Linden, Flexicurity in Belgium. A Proposal Based on Economic Principles, May 2009

2656 Michael Melvin, Lukas Menkhoff and Maik Schmeling, Exchange Rate Management in Emerging Markets: Intervention via an Electronic Limit Order Book, May 2009

2657 Susanne Neckermann, Reto Cueni and Bruno S. Frey, What is an Award Worth? An Econometric Assessment of the Impact of Awards on Employee Performance, May 2009

2658 Steven Brakman, Harry Garretsen and Charles van Marrewijk, Economic Geography within and between European Nations: The Role of Market Potential and Density across Space and Time, May 2009

2659 Giovanni Facchini and Cecilia Testa, Reforming Legislatures: Is one House better than two?, May 2009

2660 Carsten Kowalczyk and Raymond Riezman, Trade Agreements, May 2009 
2661 Oliver Falck, Stephan Heblich and Elke Luedemann, Identity and Entrepreneurship, May 2009

2662 Christian Lessmann and Gunther Markwardt, One Size Fits All? Decentralization, Corruption, and the Monitoring of Bureaucrats, May 2009

2663 Felix Bierbrauer, On the Legitimacy of Coercion for the Financing of Public Goods, May 2009

2664 Alessandro Cigno, Agency in Family Policy: A Survey, May 2009

2665 Claudia M. Buch and Christian Pierdzioch, Low Skill but High Volatility?, May 2009

2666 Hendrik Jürges, Kerstin Schneider, Martin Senkbeil and Claus H. Carstensen, Assessment Drives Learning: The Effect of Central Exit Exams on Curricular Knowledge and Mathematical Literacy, June 2009

2667 Eric A. Hanushek and Ludger Woessmann, Schooling, Cognitive Skills, and the Latin American Growth Puzzle, June 2009

2668 Ourania Karakosta, Christos Kotsogiannis and Miguel-Angel Lopez-Garcia, Does Indirect Tax Harmonization Deliver Pareto Improvements in the Presence of Global Public Goods?, June 2009

2669 Aleksandra Riedl and Silvia Rocha-Akis, Testing the Tax Competition Theory: How Elastic are National Tax Bases in OECD Countries?, June 2009

2670 Dominique Demougin and Carsten Helm, Incentive Contracts and Efficient Unemployment Benefits, June 2009

2671 Guglielmo Maria Caporale and Luis A. Gil-Alana, Long Memory in US Real Output per Capita, June 2009

2672 Jim Malley and Ulrich Woitek, Productivity Shocks and Aggregate Cycles in an Estimated Endogenous Growth Model, June 2009

2673 Vivek Ghosal, Business Strategy and Firm Reorganization under Changing Market Conditions, June 2009 